\title{
Glutamate Decarboxylases in Nonneural Cells of Rat Testis and Oviduct: Differential Expression of $\mathrm{GAD}_{65}$ and $\mathrm{GAD}_{67}$
}

\author{
*Niranjala J. K. Tillakaratne, †Mark G. Erlander, †Michael W. Collard, \\ $\S$ Karen F. Greif, and *\|ףAllan J. Tobin \\ *Department of Biology, †Neuroscience Program, \|Molecular Biology Institute, and $\pi$ Brain Research Institute, University of \\ California, Los Angeles, Los Angeles. California; $\ddagger$ Mental Health Research Institute, University of Michigan, Ann Arbor, \\ Michigan; and §Department of Biology, Bryn Mawr College, Bryn Mawr, Pennsylvania, U.S.A.
}

\begin{abstract}
Aminobutyric acid (GABA) and its synthetic enzyme, glutamate decarboxylase (GAD), are not limited to the nervous system but are also found in nonneural tissues. The mammalian brain contains at least two forms of GAD $\left(\mathrm{GAD}_{67}\right.$ and $\left.\mathrm{GAD}_{65}\right)$, which differ from each other in size, sequence, immunoreactivity, and their interaction with the cofactor pyridoxal 5'-phosphate (PLP). We used cDNAs and antibodies specific to $\mathrm{GAD}_{65}$ and $\mathrm{GAD}_{67}$ to study the molecular identity of GADs in peripheral tissues. We detected GAD and GAD mRNAs in rat oviduct and testis. In oviduct. the size of GAD, its response to PLP, its immunoreactivity, and its hybridization to specific RNA and DNA probes all
\end{abstract}

indicate the specific expression of the $\mathrm{GAD}_{65}$ gene. In contrast, rat testis expresses the $\mathrm{GAD}_{67}$ gene. The GAD in these two reproductive tissues is not in neurons but in nonneural cells. The localization of brain GAD and GAD mRNAs in the mucosal epithelial cells of the oviduct and in spermatocytes and spermatids of the testis shows that GAD is not limited to neurons and that GABA may have functions other than neurotransmission. Key Words: Glutamate decarboxylase$\gamma$-Aminobutyric acid-Oviduct-Testis-mRNAs. Tillakaratne N. J. K. et al. Glutamate decarboxylases in nonneural cells of rat testis and oviduct: Differential expression of $\mathrm{GAD}_{65}$ and $\mathrm{GAD}_{67} . J$. Neurochem. 58, 618-627 (1992).
$\gamma$-Aminobutyric acid (GABA) is a multifaceted molecule. It is the major inhibitory neurotransmitter in the vertebrate brain and may also serve as a neurotransmitter in the vertebrate PNS (Jessen et al., 1979). GABA is also involved as a neurotrophic factor during neural development (Redburn and Schousboe, 1987). GABA is not limited to the nervous system, however, but is present in many nonneural tissues, where it may serve diverse physiological functions (for reviews, see Erdö and Kiss, 1986; Erdö and Wolff, 1990). For example, in the pancreas, GABA produced in $\beta$ cells inhibits glucagon secretion by $\alpha$ cells (Rorsman et al., 1989 ), and in the testes GABA stimulates production of testosterone (Ritta et al., 1987). GABA thus is an important signaling molecule in both neural and nonneural systems.

The synthesis of GABA in brain depend mainly on the activity of glutamate decarboxylase (GAD; L-glutamic 1-carboxylase; E.C. 4.1.1.15). Several groups have demonstrated GAD heterogeneity with respect to molecular size, interaction with pyridoxal phosphate (PLP), and subcellular localization (Denner and $\mathrm{Wu}$, 1985; Spink et al., 1985; Legay et al., 1987; Chang and Gottlieb, 1988; reviewed by Martin, 1987; Erlander and Tobin, 1991). This laboratory has recently established that rat brain contains two forms of GAD, with molecular sizes of 65,000 and 67,000 . These GADs $\left(G D_{65}\right.$ and $G A D_{67}$, respectively) are the products of two genes, each of which is present in a single copy in the rat genome (Erlander et al., 1991).

The molecular identity of nonneural GAD, however, remains obscure. Reports from the last 22 years indicate that properties of nonneural GADs resemble brain GADs to differing extents, depending on the tissue examined. For example, immunological and enzymatic studies suggest that GADs in oviduct, adrenal chromaffin cells, and pancreatic $\beta$ cells are similar to brain GAD, whereas GAD species in heart, kidney, and liver are different (Wu and Roberts, 1973; Wu, 1977; Wu et al., 1978, 1986b; Vincent et al., 1983; Apud et al.,
Received March 13, 1991; revised manuscript received June 26. 1991; accepted June 28, 1991.

Address correspondence and reprint requests to Dr. A. J. Tobin at Department of Biology, University of California, Los Angeles, Los Angeles, CA 90024-1606, U.S.A.
Abbreviations used: GABA, $\gamma$-aminobutyric acid; GAD, glutamate decarboxylase: $\mathrm{GAD}_{65}$ and $\mathrm{GAD}_{67}$, glutamate decarboxylase having molecular sizes of 65,000 and 67,000 , respectively; PLP, pyridoxal phosphate; SDS, sodium dodecyl sulfate; SSC, saline-sodium citrate. 
1984; Erdö et al., 1984, 1989; Kataoka et al., 1984; Baekkeskov et al., 1990). An antiserum to rat brain GAD (Oertel et al., 1981b) shows immunoreactivity with the mucosal epithelial cells in the rat oviduct (Erdö et al., 1989). GAD activity in renal cortex does not depend on PLP to the same extent as in brain, adrenal chromaffin cells, and oviduct (Whelan et al., 1969; Oertel et al., 1981a; Goodyer et al., 1982; Kataoka et al., 1984; Erdö et al., 1984).

Isolation and characterization of a brain GAD cDNA (Kaufman et al., 1986) allowed us to study nonneural GAD using molecular hybridization techniques. Using this cDNA (which encodes $G_{A D}$ ), we have demonstrated the presence of $\mathrm{GAD}_{67}$ RNAs in the testes of rats (Tillakaratne and Tobin, 1986; Tobin, 1989). $\mathrm{GAD}_{67}$ RNAs are also present in mice, guinea pigs, monkeys, and humans and are specifically localized in the germ cells of the rat testis (Persson et al., 1990). Furthermore, GAD-like immunoreactivity is present in spermatozoa.

Our laboratory has recently found a second form of GAD $\left(\mathrm{GAD}_{65}\right)$ in brain (Erlander et al., 1991). In view of this finding, we asked whether these two forms of GAD are also present in other tissues. To address this question, we used cDNAs and antibodies specific to either $\mathrm{GAD}_{65}$ or $\mathrm{GAD}_{67}$ to study the size, distribution, and localization of GAD in nonneural tissues.

\section{MATERIALS AND METHODS}

\section{Isolation of rat tissues}

Adult and prepubertal Wistar rats were killed after halothane anesthesia, and the tissues were quickly frozen in liquid nitrogen and stored at $-70^{\circ} \mathrm{C}$. Female animals were randomly cycling.

\section{Cell isolation and culture}

Sertoli cell cultures were prepared from 22-day-old rats by the method of Dorrington and Fritz (1975) and cultured at $32^{\circ} \mathrm{C}$ in Ham's F- 12 medium supplemented with $9 \mathrm{mM}$

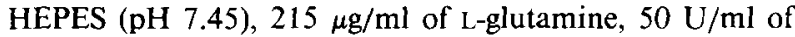
penicillin, $50 \mu \mathrm{g} / \mathrm{ml}$ of streptomycin, $50 \mu \mathrm{g} / \mathrm{ml}$ of gentamicin, and amphotericin B $0.625 \mu \mathrm{g} / \mathrm{ml}$ of (Fungizone). Peritubular (myoid) cultures were prepared from adult testis as described before (Morales et al., 1987) and cultured in Dulbecco's modified Eagle's medium supplemented with 3\% horse serum at $37^{\circ} \mathrm{C}$. Germinal cells were isolated using sequential collagenase and trypsin treatment, resuspended in F-12 medium supplemented with $6 \mathrm{mM}$ pyruvate and $3 \mathrm{~m} M$ lactate, and fractionated on $1-4 \%$ bovine serum albumin gradients in $\mathrm{F}$ 12 medium at unit gravity in a Staput apparatus (Miestrish et al., 1973). Isolated cells were routinely monitored by phasecontrast microscopy and usually contained $<2 \%$ contamination by Sertoli, Leydig, or peritubular cell types.

TM-4, a Sertoli cell line, and LC-540, a Leydig cell line derived from mouse testes, were purchased from the American Type Culture Collection and grown according to their culture conditions.

\section{RNA isolation}

Tissues were homogenized in $4 M$ guanidinium thiocyanate, and total RNA was isolated by the method of Chirgwin et al. (1979). Poly(A) ${ }^{+}$RNA was isolated by affinity chro- matography by two rounds of binding to an oligo(dT) cellulose (Collaborative Research or BRL) as previously described (Wood et al., 1986).

\section{Northern blot hybridization}

RNA was treated with formaldehyde, separated by gel electrophoresis in $1 \%$ agarose, and transferred to Biotrans nylon membranes (Maniatis et al., 1982). When DNA probes were used, membranes were prehybridized for $4-12 \mathrm{~h}$ at $42^{\circ} \mathrm{C}$ in $50 \%$ formamide, $5 \times$ saline-sodium citrate (SSC; $1 \times$ SSC comprises $0.15 \mathrm{M} \mathrm{NaCl}$ and $0.015 \mathrm{M}$ sodium citrate, $\mathrm{pH}$ 7.0 ), $50 \mathrm{mM}$ sodium phosphate ( $\mathrm{pH} 6.5$ ), $5 \times$ Denhardt's solution, $0.5 \%$ sodium dodecyl sulfate (SDS), and $250 \mu \mathrm{g} / \mathrm{ml}$ of heat-denatured salmon sperm DNA (Segovia et al., 1990). Hybridizations proceeded for $18-24 \mathrm{~h}$ at $42^{\circ} \mathrm{C}$ in the same solution. After hybridization, blots were washed at room temperature three times for 5 min each in $2 \times$ SSC and $0.1 \%$ SDS, followed by two 30 -min washes at $50^{\circ} \mathrm{C}$ in $0.1 \times$ SSC and $0.1 \%$ SDS. Filters were then exposed to Kodak XAR-5 film for $1-3$ days at $-70^{\circ} \mathrm{C}$.

When RNA probes were used, membranes were prehybridized for $2-6 \mathrm{~h}$ at $60^{\circ} \mathrm{C}$ in $400 \mathrm{~m} M$ sodium phosphate (pH 7.2), $1 \mathrm{~m} M$ EDTA, $1 \mathrm{mg} / \mathrm{ml}$ of bovine serum albumin (fraction V; Sigma), and 50\% formamide (Church and Gilbert, 1984; Khrestchatisky et al., 1991). The ${ }^{32}$ P-labeled RNA probe was added to the prehybridization solution, and, after hybridization at $60^{\circ} \mathrm{C}$ overnight, the membranes were washed twice for $30 \mathrm{~min}$ at room temperature in $2 \times \mathrm{SSC}$ and $0.1 \%$ SDS and twice for $2 \mathrm{~h}$ in $0.1 \times$ SSC and $0.1 \%$ SDS at $72^{\circ} \mathrm{C}$. ${ }^{32} \mathrm{P}$-labeled cDNA probes or RNA probes were added to the hybridization solution at a concentration of $>1-3 \times 10^{6} \mathrm{cpm} /$ $\mathrm{ml}$. After exposure to film, the probe was removed from the blots by washing at $65^{\circ} \mathrm{C}$ in $50 \%$ formamide and $10 \mathrm{mM}$ sodium phosphate $(\mathrm{pH} 6.5)$ for $1 \mathrm{~h}$. The stripped blots were rinsed in $2 \times$ SSC and $0.1 \%$ SDS and exposed to film to check for complete removal of probe.

\section{Preparation of cDNA probes}

cDNAs were labeled by random priming (Feinberg and Vogelstein, 1984). The $\mathrm{GAD}_{67} \mathrm{cDNA}$ probe used in this study was isolated from a $\lambda g t-11$ library of a rat whole brain using the feline $\mathrm{GAD}_{67}$ cDNA (Kaufman et al., 1986; Kobayashi et al., 1987). This clone contained all of the coding region, $0.1 \mathrm{~kb}$ of the $5^{\prime}$ untranslated region, and $1.0 \mathrm{~kb}$ of the $3^{\prime}$ untranslated region. Rat $\mathrm{GAD}_{65} \mathrm{CDNA}$ contains all the coding region, $0.07 \mathrm{~kb}$ of the $5^{\prime}$ untranslated region, and $0.4 \mathrm{~kb}$ of the $3^{\prime}$ untranslated region (Erlander et al., 1991).

\section{In situ hybridization}

Testes and oviduct were immediately removed from animals killed with halothane and placed in O.C.T. (TissueTek) in embedding molds. Blocks were frozen on dry ice and either sectioned immediately or stored at $-70^{\circ} \mathrm{C}$. Transfer sections $(10 \mu \mathrm{m})$ were cut using a cryostat and thaw-mounted onto gelatin-coated slides as previously described (Wuenschell et al., 1986). After air-drying, slides were postfixed for $30 \mathrm{~min}$ in 4\% paraformaldehyde in phosphate-buffered saline, rinsed, dehydrated, and stored at $-70^{\circ} \mathrm{C}$ with desiccant until processed for in situ hybridization. ${ }^{35}$ S-labeled cRNA transcripts were prepared from rat $\mathrm{GAD}_{65}$ and $\mathrm{GAD}_{67}$ CDNAs according to the technique of Wuenschell et al. (1986). Both sense and antisense probes were prepared and subjected to limited alkaline hydrolysis to give probes of 100-200 bases. Probe (3$5 \mathrm{ng}$ ) was added in $50 \mu \mathrm{l}$ of solution. Each slide was then coverslipped and incubated for $16 \mathrm{~h}$ at $50^{\circ} \mathrm{C}$. 


\section{Measurement of GAD activity}

GAD activity was measured according to the procedure of Krieger and Heller (1984). The production of ${ }^{14} \mathrm{CO}_{2}$ from decarboxylation of $\mathrm{L}-\left[1-{ }^{14} \mathrm{C}\right]$ glutamate $(52.6 \mathrm{Ci} / \mathrm{mmol}$; NEN) was determined in tissue homogenates in the presence or absence of $100 \mathrm{mM}$ PLP. Each homogenate was assayed at least in triplicate. The ratio of induction by PLP was determined for each homogenate by dividing total cpm per milligram of protein per hour in the presence of PLP by the corresponding value in the absence of PLP. GAD activity in immunoprecipitated tissue homogenates was measured as above. Protein concentrations were determined by the Bradford colorimetric method (Bio-Rad) using bovine serum albumin as the standard (Bradford, 1976).

\section{Western blots}

Tissue homogenates or immunoprecipitated tissue samples were separated by electrophoresis on a $10 \%$ acrylamide-SDS gel and electrophoretically transferred to nitrocellulose using a Transblot cell (Bio-Rad) as previously described (Erlander et al., 1991). Blots were incubated with $2 \%$ bovine serum albumin (fraction V), $1 \%$ gelatin, and $1 \%$ Triton X-100 in phosphate-buffered saline for $1 \mathrm{~h}$ followed by primary antiserum $\mathrm{K}-2$, which mainly recognizes $\mathrm{GAD}_{67}$ (Kaufman et al., 1991), or GAD-6, which only recognizes GAD $_{65}$ (Chang and Gottlieb, 1988). For immunoblotting, all antisera were used at dilutions of 1:2,000. GAD-6 was used as a 1:2,000 dilution of ascites fluid. Filters were extensively washed and, in the case of GAD-6, incubated with rabbit anti-mouse IgG (Cappel). After the unbound secondary antibody was washed off, the filters were incubated with ${ }^{125} \mathrm{I}$-protein $A$ and exposed to Kodak XAR5 film.

\section{Immunoprecipitation}

Tissue homogenates $(100 \mu \mathrm{l})$ were incubated at $0^{\circ} \mathrm{C}$ for 40 min with $\mathrm{K}-2$ antiserum $(2 \mu \mathrm{l})$ or with GAD-6 ascites fluid $(0.1 \mu \mathrm{l})$, followed by incubation $(20 \mathrm{~min})$ with rabbit antimouse IgG for the GAD-6 antibody, and precipitated with CL-4B Sepharose-protein A beads (CL-4B Sepharose; Pharmacia) (Kaufman et al., 1991).

\section{Immunohistochemistry}

Adult rat females were anesthetized with pentobarbital sodium (Nembutal) and perfused through the aorta with $4 \%$ paraformaldehyde in $0.12 \mathrm{M}$ phosphate buffer ( $\mathrm{pH} \mathrm{7.3)}$. Oviducts were dissected and immersed in $20 \%$ sucrose overnight. Tissue was embedded in OCT compound and frozen on dry ice. Sections were cut at $10 \mu \mathrm{m}$ using a cryostat microtome at $-20^{\circ} \mathrm{C}$, placed on gelatin-coated slides (room temperature), and stored at $-70^{\circ} \mathrm{C}$ with desiccant for later use. Immunohistochemical detection was carried out as described by Kaufman et al. (1991). The sections were rinsed in $0.1 \mathrm{M}$ Tris buffer containing $1 \% \mathrm{NaCl}$ (wash buffer) and then blocked with normal goat serum diluted $1: 30$ for $1 \mathrm{~h}$. K-2 antiserum and preimmune serum were used at $1: 1,000,1$ : 2,000 , and $1: 4,000$ dilutions. The tissue sections were incubated in the primary antiserum for $\sim 4 \mathrm{~h}$ at room temperature and overnight at $4^{\circ} \mathrm{C}$. Tissue sections were rinsed in wash buffer and incubated for $1 \mathrm{~h}$ in goat anti-rabbit $\mathrm{IgG}$ at $1: 100$ in $1 \%$ normal goat serum. After rinsing with wash buffer, the immunoreactivity was detected through the peroxidase-antiperoxidase method. Immunohistochemical immunoreactivity with GAD-6 monoclonal antibody was also detected through the peroxidase-antiperoxidase method, with 1:500 and 1:1,000 dilutions of GAD-6 and goat anti-mouse IgG at 1:75. Control sections were processed similarly, except for the substitution of preimmune rabbit serum or the omission of the GAD-6 antibody; controls showed no specific staining.

\section{RESULTS}

\section{Both $\mathrm{GAD}_{67}$ and $\mathrm{GAD}_{65}$ RNAs are present in oviduct and testis}

We first determined which peripheral tissues expressed $\mathrm{GAD}_{65}$ and $\mathrm{GAD}_{67}$ mRNAs. Of the 12 peripheral tissues examined, only oviduct and testis contained RNAs that hybridized to $\mathrm{GAD}_{67}$ and $\mathrm{GAD}_{65}$ cDNAs (Fig. 1). In contrast to the single 3.7-kb GAD 67 RNA in brain, testis and oviduct expressed multiple species of $\mathrm{GAD}_{67}$ RNA (Fig. 1A). Testis contained six
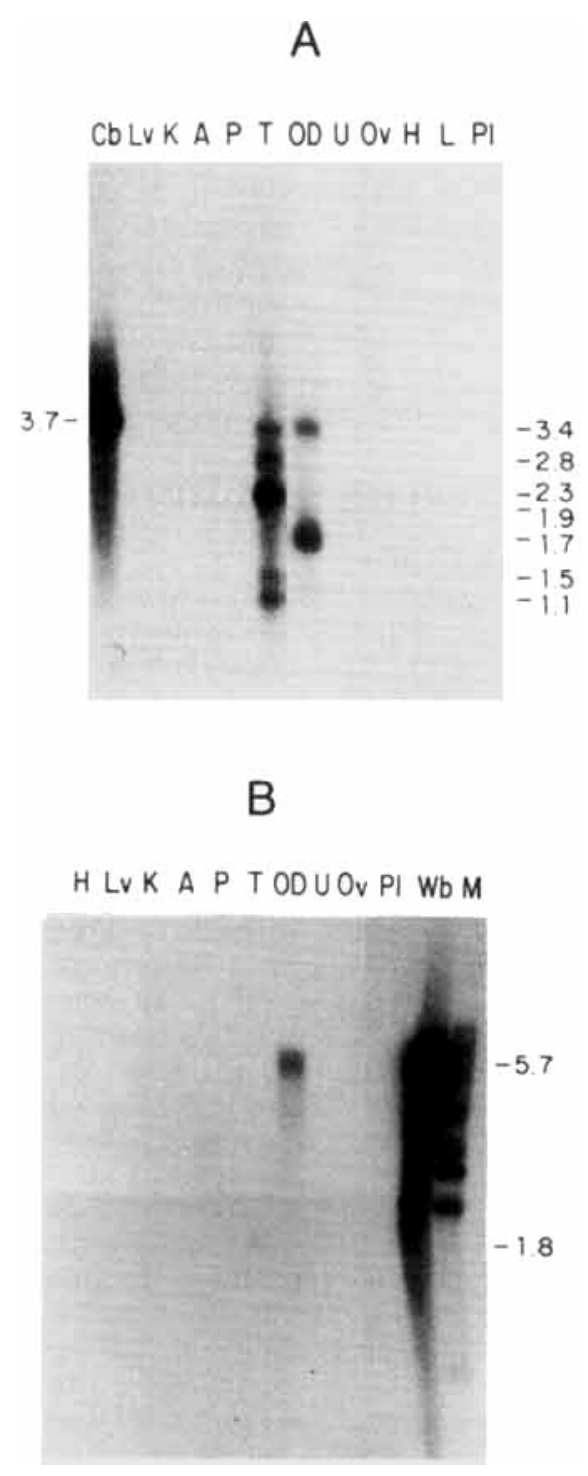

FIG. 1. Northern blots of RNA from rat tissues hybridized to (A) $\mathrm{GAD}_{67}$ and $(\mathrm{B}) \mathrm{GAD}_{65}$ CDNA. Each lane contains $10 \mu \mathrm{g}$ of poly $(\mathrm{A})^{+}$ RNA except that the cerebellum $(\mathrm{Cb})$ lane contains $0.3 \mu \mathrm{g}$. $\mathrm{Lv}$, liver; K, kidney; A, adrenal gland; $P$, pancreas; $T$, testis; $O D$, oviduct; $U$, uterus; Ov, ovary; $H$, heart; $L$, lung; $P I$, placenta; $W b$, whole brain; $M$, RNA ladder. 
species of $\mathrm{GAD}_{67} \mathrm{RNA}$, whereas oviduct had two. In adult testis, $\mathrm{GAD}_{67}$ cDNA hybridized to RNAs of 3.4, $2.8,2.3,1.9,1.5$, and $1.1 \mathrm{~kb}$. Oviduct contained 3.4and $1.7-\mathrm{kb}$ RNAs. Testis and oviduct thus shared only the 3.4-kb GAD 67 RNA. GAD 65 cDNA hybridized to a 5.7-kb RNA species in oviduct, the same size as $\mathrm{GAD}_{65} \mathrm{mRNA}$ in brain, and to a rare 1.8-kb RNA in testis (Fig. 1B). Hybridization of both $\mathrm{GAD}_{65}$ and $\mathrm{GAD}_{67}$ probes persisted even at high stringency $(0.1 \times$ SSC and $0.1 \%$ SDS at $72^{\circ} \mathrm{C}$ ), a result showing strong sequence similarities among GAD RNAs in testis, oviduct, and brain.

\section{GAD activity responds differently to PLP in oviduct} and testis

GAD activity was present in homogenates of several tissues, at levels lower than in brain, including (in order of decreasing specific activity) kidney, oviduct, liver, testis, lung, ovary, pancreas, adrenal gland, and spleen (Table 1).

In all tissues except the oviduct and cerebellum, addition of PLP to the assay did not affect GAD activity. The stimulatory effect of PLP was greater in the oviduct (3.2-fold) than in the adult cerebellum (twofold). The increase of GAD activity with exogenously added PLP reflects the presence of apo-GAD (inactive GAD, no PLP bound), most of which is $\mathrm{GAD}_{65}$ (Martin, 1987; Erlander and Tobin, 1991; Kaufman et al., 1991). Of the GAD activity in oviduct, $87 \%$ was immunoprecipitated by GAD-6 antiserum, which is specific to GAD $_{65}$ (Chang and Gottlieb, 1988), whereas only $12 \%$ was precipitated by $\mathrm{K}-2$, which is specific to $\mathrm{GAD}_{67}$ (Kaufman et al., 1991). In testis, 30\% of GAD activity was precipitated by K-2. No significant decrease of GAD activity was seen in any other tissues after immunoprecipitation using these two antibodies. Immunoprecipitation data thus support the conclusion that most of the GAD in oviduct is $\mathrm{GAD}_{65}$, whereas testis GAD is predominantly $\mathrm{GAD}_{67}$.

TABLE 1. PLP dependence and immunoprecipitation of $G A D$ activities in peripheral tissues

\begin{tabular}{|c|c|c|c|c|}
\hline \multirow[b]{2}{*}{ Tissue } & \multirow{2}{*}{$\begin{array}{l}\text { GAD Activity } \\
\text { (nmol of } \\
\mathrm{CO}_{2} / \mathrm{mg} \text { of } \\
\text { protein } / \mathrm{h} \text { ) }\end{array}$} & \multirow{2}{*}{$\begin{array}{l}\text { Stimulation (fold) } \\
\text { of GAD activity } \\
\text { by added PLP }\end{array}$} & \multicolumn{2}{|c|}{$\begin{array}{c}\% \text { of GAD } \\
\text { activity } \\
\text { precipitated by }\end{array}$} \\
\hline & & & $\mathrm{K}-2$ & GAD-6 \\
\hline Brain & $219.2 \pm 4.1$ & 2.0 & 75 & 77 \\
\hline Oviduct & $11.0 \pm 0.16$ & 3.2 & 12 & 86 \\
\hline Ovary & $3.4 \pm 0.05$ & 1.2 & 10 & 8 \\
\hline Testis & $6.2 \pm 0.62$ & 1.0 & 30 & 6 \\
\hline Liver & $7.9 \pm 0.45$ & 1.1 & 9 & 6 \\
\hline Kidney & $23.3 \pm 3.4$ & 1.1 & 5 & 2 \\
\hline
\end{tabular}

K-2 and GAD-6 antiserum were used to immunoprecipitate selectively $\mathrm{GAD}_{67}$ or $\mathrm{GAD}_{65}$, respectively, from tissue homogenates as described in Materials and Methods. The enzymatic activity of the remaining form of GAD in solution was examined with and without the addition of exogenous PLP cofactor. Data are mean \pm SD values $(n=4)$.
A
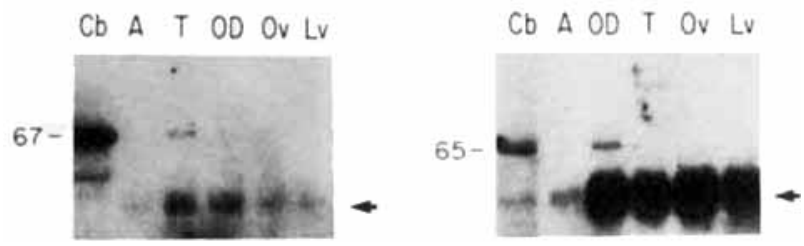

FIG. 2. Immunoblots of $\mathrm{GAD}_{67}$ and $\mathrm{GAD}_{65}$ proteins in peripheral tissues. Each lane except cerebellum $(\mathrm{Cb})$ contains proteins immunoprecipitated with either (A) K-2 or (B) GAD-6 and detected with the same antibody. A, adrenal; T, testis; $O D$, oviduct; $O v$, ovary; Lv, liver. The $\mathrm{Cb}$ lane contains $100 \mu \mathrm{g}$ of protein of direct tissue homogenate. $\mathrm{GAD}_{67}$ immunoreactivity was seen in $\mathrm{OD}$ at longer exposures of the autoradiogram. The immunoreactivity seen below (indicated by arrows) $G_{A D}$ and $G A D_{65}$ is due to immunoglobulins used in the immunoprecipitations. The bands that correspond to immunoglobulins are also present in the control immunoprecipitation reactions with preimmune sera.

\section{The molecular size of GAD is 65,000 in oviduct and 67,000 in the testis}

We did not detect immunoreactive $\mathrm{GAD}_{65}$ or $\mathrm{GAD}_{67}$ protein in extracts of liver, kidney, spleen, adrenal gland, pancreas, ovary, heart, and lung by western blot analysis (using tissue homogenates containing $100 \mu \mathrm{g}$ of protein per lane) or after immunoprecipitation with $\mathrm{K}-2$ and GAD-6. Rat oviduct contained mainly $\mathrm{GAD}_{65}$, with low levels of $\mathrm{GAD}_{67}$ (Fig. 2). In contrast, testis contained only $\mathrm{GAD}_{67}$. The sizes of the $\mathrm{GAD}_{65}$ and $\mathrm{GAD}_{67}$ in oviduct and testis are the same as in brain.

\section{$G D_{65}$ and $G A D_{67}$ RNAs and immunoreactivity is} present in the mucosal epithelium of rat oviduct

We localized GAD and GAD mRNAs in the oviduct by immunohistochemistry and in situ hybridization. We observed both $\mathrm{GAD}_{65}$ and $\mathrm{GAD}_{67}$ immunoreactivity in the mucosal epithelium of the rat oviduct, with intense $\mathrm{GAD}_{65}$ immunoreactivity in the mucosal epithelial cells (Fig. 3). The ampulla (the part of the oviduct closer to ovary) contains more immunoreactive cells than the isthmus (closer to the uterus). Some $\mathrm{GAD}_{67}$ immunoreactivity was also seen in the cells of the oviductal epithelium.

In situ hybridization revealed that $\mathrm{GAD}_{65}$ RNAs are in the mucosal epithelium of the rat oviduct. Muscle and serosa layers of the oviduct did not contain either GAD RNA (Fig. 4). Mucosal epithelial cells also contained low levels of $\mathrm{GAD}_{67}$ RNA.

\section{Germ line cells in testis contain $G D_{67}$ RNAs and GAD activity}

To determine which cells in the testis contain GAD, we performed cell fractionation using unit gravity bovine serum albumin gradients. The purity of the cell populations isolated by this method was previously established (Collard et al., 1990). We then analyzed the 

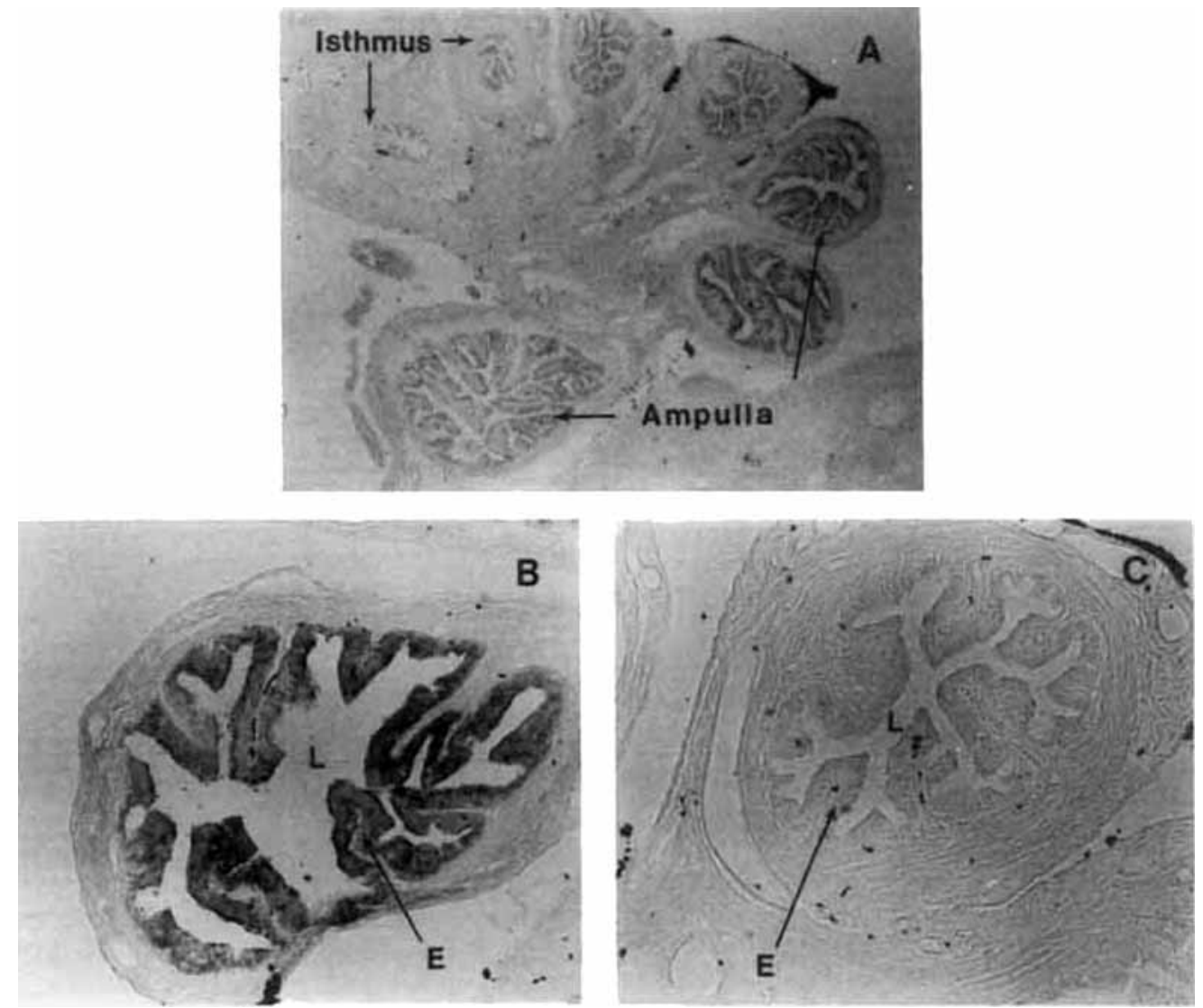

FIG. 3. $\mathrm{GAD}_{65}$ immunoreactivity in the mucosal epithelium of the rat oviduct. A: $\mathrm{GAD}_{65}$ immunoreactivity in various parts of the rat oviduct. More immunoreactivity is present in the oviductal ampulla than in the isthmus. B: $G_{A D} D_{65}$ immunoreactivity is present in the epithelial cells (E) of the oviduct. In $A$ and $B$, immunoreactivity was detected with GAD-6 antibody. C: Control.

separated cells for GAD activity and GAD mRNAs (by northern blotting).

Our data show that $\mathrm{GAD}_{67}$ RNAs are in germinal cells but not in somatic cells (Fig. 5). For example, $\mathrm{GAD}_{67}$ RNAs were present in total germinal cells, spermatocytes, and round spermatids but not in peritubular, Leydig, or Sertoli cells. Isolated germ cells also contained GAD activity (Table 2). As in the case of whole testis, addition of PLP to the assay did not affect the GAD activity. In situ hybridization to sections of testis showed $G_{A D} D_{67}$ RNA associated with the seminiferous epithelium, with signal in spermatocytes and spermatids but not in interstitial cells (data not shown).

\section{Levels of individual $\mathrm{GAD}_{67}$ RNAs change during postnatal testicular development}

$\mathrm{GAD}_{67}$ RNAs were undetectable in the testes at 5 days after birth (Fig. 6). The first detectable $G A D_{67}$ RNA in the testes was the 1.9-kb species, which appeared at postnatal day 10 . The level of this species was highest at postnatal day 20 but remained prominent throughout the first 10 weeks of postnatal life. Other GAD RNAs $(3.4,2.8$, and $2.3 \mathrm{~kb})$ appeared at postnatal day 34 . We first detected the $1.1-\mathrm{kb}$ species at postnatal day 54 and the $1.5-\mathrm{kb}$ species at postnatal day 72 .
The relative proportions of individual $\mathrm{GAD}_{67}$ transcripts in older rats ( 6 months) were different from those of 72-day-old rats. The $2.3-\mathrm{kb} \mathrm{GAD}_{67} \mathrm{RNA}$ was more prominent in older than in younger rats.

\section{DISCUSSION}

\section{Rat oviduct GAD is primarily $\mathrm{GAD}_{65}$}

The sizes of the GAD polypeptides and mRNAs indicate that both brain GADs $\left(\mathrm{GAD}_{65}\right.$ and $\left.\mathrm{GAD}_{67}\right)$ are present in the oviduct, with $\mathrm{GAD}_{65}$ being the predominant form. Our findings are in agreement with many reports that GABA production in the rat oviduct depends on a GAD similar to that in brain. For example, biochemical properties, such as coenzyme requirement, thermosensitivity, substrate kinetics, and $\mathrm{pH}$ dependence of oviductal GAD, are similar to those of brain (Erdö et al., 1984). An antiserum to rat brain GAD (Oertel et al., 1981b) immunoprecipitated GAD activity in rat oviduct and posterior pituitary but not in liver, anterior pituitary, kidney, or ovary (Celotti et al., 1986). Using the same antiserum, Erdö et al. (1989) found GAD immunoreactivity in the mucosal epithelial cells of rat oviduct. The antiserum used in these studies, however, recognizes both $\mathrm{GAD}_{65}$ and $\mathrm{GAD}_{67}$ (Kaufman et al., 1986, 1991). 

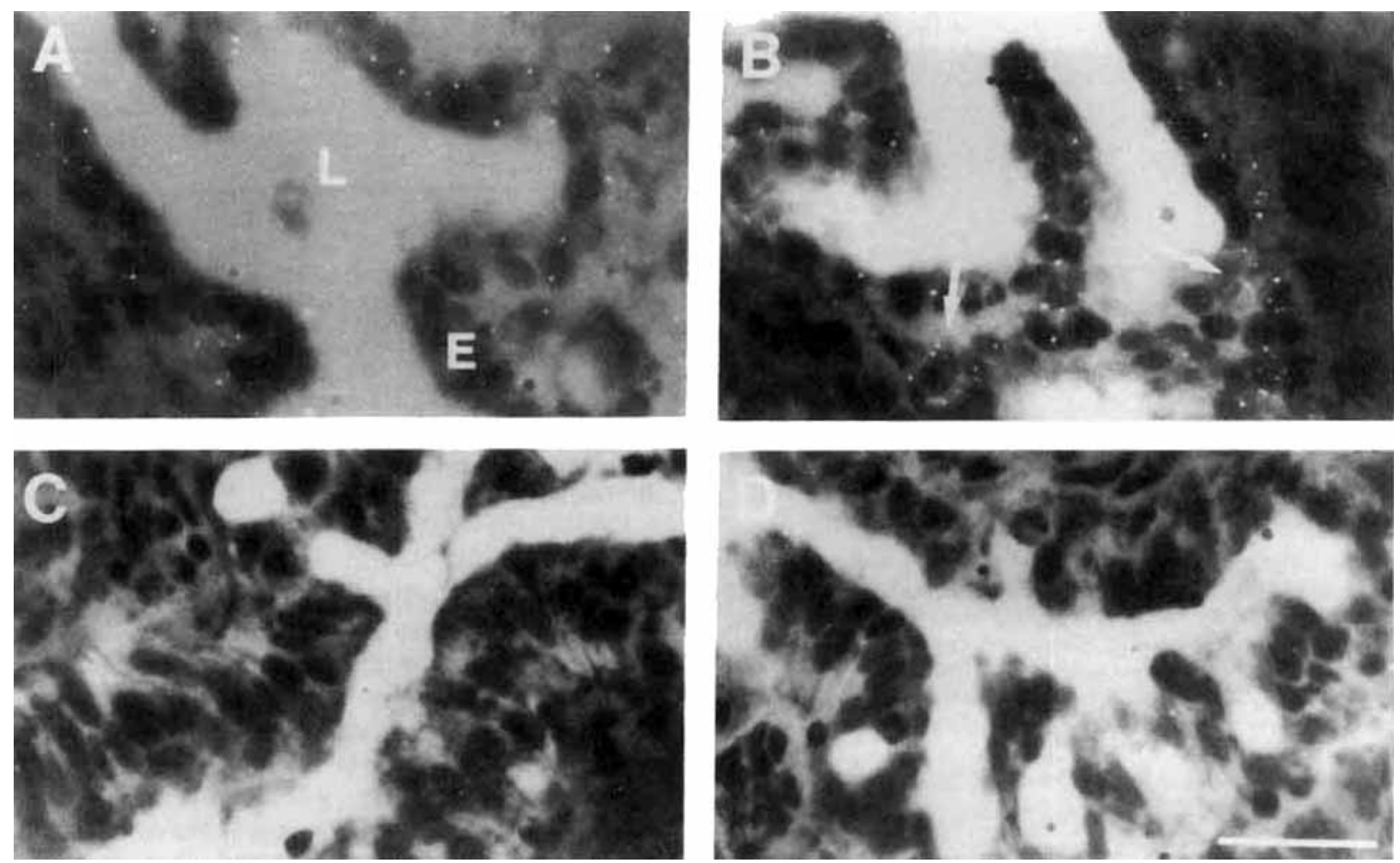

FIG. 4. Localization of GAD RNAs in the oviduct by in situ hybridization. Transverse sections of oviduct hybridized with ${ }^{35} \mathrm{~S}_{-1 a b e l e d} \mathrm{GAD}_{67}$ (A-anti-sense, $C$-sense) and $\mathrm{GAD}_{65}$ (B-anti-sense, $\mathrm{D}$-sense). $\mathrm{L}$, lumen of the oviduct; $\mathrm{E}$, epithelial cells of the oviduct. Arrows indicate labeled epithelial cells. Bar $=10 \mu \mathrm{m}$.

Celloti et al. (1986) and Fernandez et al. (1985) have suggested that GABA and GAD in the rat oviduct may derive from GABA neurons, because denervation reduces both GABA and GAD activity. Immunocytochemistry reveals, however, that most of the GABA and GAD are not in neurons but in oviductal epithelium (Erdö et al., 1989). Our in situ hybridizations and immunohistochemical staining show that $\mathrm{GAD}_{65}$ and $\mathrm{GAD}_{67}$ are made in the mucosal epithelial cells of rat oviduct, a conclusion confirming the nonneural origin of GABA and GAD.

\section{Rat testis contains $\mathbf{G A D}_{67}$}

In contrast to the oviduct, the testis does not contain PLP-dependent GAD activity. We detected strong hybridization of brain $\mathrm{GAD}_{67}$ cDNA to multiple RNA species in the testis, a finding suggesting that testis and brain GAD derive from the same gene. In fact, Persson et al. (1990) showed that a stretch of 69 amino acids derived from a GAD cDNA isolated from human testis using our feline $G_{A D}$ is identical to that of the rat brain.

Germ cells, including spermatocytes and round spermatids, contain $\mathrm{GAD}_{67}$ RNA, also in agreement with the results of Persson et al. (1990). These, as well as elongated spermatids, also contain GAD activity, an observation showing that the GAD RNAs make functional protein. The presence of elevated GAD ac- tivity but low GAD RNA levels in elongating spermatids suggests GAD RNAs are degraded after round spermatid development whereas GAD protein persists. We have observed a similar pattern of mRNA synthesis and protein production for proenkephalin (M. W. Collard, unpublished data).

The major species of $\mathrm{GAD}_{67}$ RNA in the brain is $3.7 \mathrm{~kb}$ long, whereas the longest $\mathrm{GAD}_{67} \mathrm{RNA}$ in the testis is $\sim 3.4 \mathrm{~kb}$. Like GAD mRNA, the mRNAs encoding the opioid peptide precursors preproenkephalin, proopiomelanocortin, and dynorphin show different transcript sizes in brain and testis (Chen et al., 1984; Pintar et al., 1984; Kilpatrick et al., 1985). The multiple, testis-specific $\mathrm{GAD}_{67}$ RNAs may result from differential promoter usage or from differential splicing of a single $\mathrm{GAD}_{67}$ pre-mRNA.

We do not yet know which transcripts encode enzymatically active $\mathrm{GAD}_{67}$. The 3.4-, 2.8-, 2.3-, and 1.9$\mathrm{kb}$ species are long enough to encode a full-length $\left(67,000-\mathrm{M}_{\mathrm{r}}\right)$ GAD polypeptide, but the 1.1- and 1.5$\mathrm{kb}$ species are not.

\section{$\mathrm{GAD}_{67}$ RNAs appear differentially during postnatal} testicular development

Six distinct $\mathrm{GAD}_{67}$ RNAs are differentially expressed during the postnatal development of rat testis. All of these RNAs occur at elevated levels in isolated germ cells relative to whole testis or other testicular cell types. 


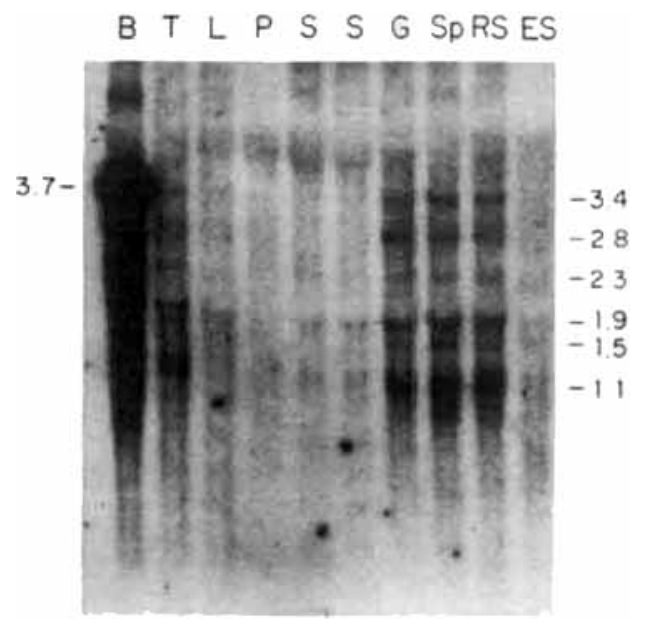

FIG. 5. Cellular localization of $\mathrm{GAD}_{67}$ RNAs in fractionated rat testicular cells. Each lane of this northern blot contains $10 \mu \mathrm{g}$ of total RNA from brain (B), testis (T), acutely isolated Leydig cells (L). peritubular or myoid cells $(P)$, Sertoli cells cultured in the absence (lane 5) and presence (lane 6) of $100 \mu \mathrm{M}$ dibutyryl cAMP (S), total germinal cells (G), spermatocytes (Sp), round spermatids (RS), and elongating spermatids (ES). The blot was hybridized with a ${ }^{32} \mathrm{P}$. labeled $\mathrm{GAD}_{67}$ antisense RNA probe

The 1.9-kb GAD RNA, the first RNA species to appear, is detected at postnatal day 10 , when it accounts for at least $0.003 \%$ of the poly $(\mathrm{A})^{+}$RNA.

In addition to the 1.9-kb GAD RNA, several other GAD RNAs are sequentially expressed between postnatal days 34 and 72 . During pubertal development, the 1.9-kb GAD RNA predominates. In the adult, however, the predominant GAD RNA is the 2.3-kb species. This developmental switch resembles that reported for the two forms of proenkephalin mRNA, which are also differentially regulated during the development of testis (Kilpatrick and Borland, 1987).

$\mathrm{GAD}_{67}$ RNAs are present at higher levels at postnatal days 54 and 72 than at postnatal day 34 and at their highest level in 6-month-old rats. Low levels of GAD RNAs in the prepubertal animals may be due to the low number of germ cells compared with the adults, because degeneration of germ cells occurs during the pubertal development of the rat (Russell et al., 1987). As development progresses, fewer germ cells degenerate. A progressive increase in content of GAD RNAs may result from this increased survival.

\section{Function of GABA in oviduct and testis}

The function of GABA and GAD in the oviduct and the testis is unknown. Erdö and Wolff (1990) suggested a morphogenetic role for GABA in the oviduct. This inference is based on the ability of benzodiazepines to block the migration of basal bodies during ciliogenesis in the oviduct (Boisvieux-Ulrich et al., 1987) and the appearance of GABA-like immunoreactivity in basal bodies of ciliated cells in the oviduct (Erdö et al., 1986).

GABA may also play a role in secretion in the oviduct. $\mathrm{GAD}_{65}$ is present at high levels in secretory cells
TABLE 2. GAD activities in testicular cells

\begin{tabular}{lcc}
\hline \multicolumn{1}{c}{ Tissue } & $\begin{array}{c}\text { GAD activity } \\
\text { (nmol of } \\
\mathrm{CO}_{2} / \mathrm{mg} \text { of } \\
\text { protein/h) }\end{array}$ & $\begin{array}{c}\text { Stimulation (fold) } \\
\text { of GAD activity } \\
\text { by added PLP }\end{array}$ \\
\hline Brain & $219.2 \pm 4.1$ & 2.0 \\
Spermatocytes & $3.67 \pm 0.66$ & 0.95 \\
Round spermatids & $4.58 \pm 0.61$ & 1.0 \\
Elongating spermatids & $6.09 \pm 0.16$ & 1.0 \\
TM-4 (Sertoli cell line) & $2.5 \pm 0.32$ & 1.1 \\
LC-540 (Leydig cell & $0.23 \pm 0.03$ & 1.1 \\
\hline line) &
\end{tabular}

GAD activity in these homogenates was measured with and without the addition of exogenous PLP cofactor. Data are mean \pm SD values $(n=4)$.

of the oviductal epithelium, which are also the predominant cells that accumulate GABA (Erdö and Amenta, 1986). Ovarian hormones, estrogen, and progesterone regulate the structural and biochemical characteristics of the oviduct (Karkun, 1979). Secretory and ciliary changes occur in the mucosal epithelium during the reproductive cycle. Significant changes in GABA and GAD levels also occur in the oviduct during the estrous cycle and gestation and after ovariectomy (Del Rio, 1981; Erdö, 1984; Fernandez-Pardal et al., 1984; Duvilanski et al., 1985; Celotti et al., 1986, 1987; Louzan et al., 1986; Murashima and Kato, 1986).

The presence of both forms of GAD in the oviduct may reflect different functional roles for each form. For example, one form may be involved in ciliary motility, whereas the other form is involved in secretory function. These forms may be subject to differential

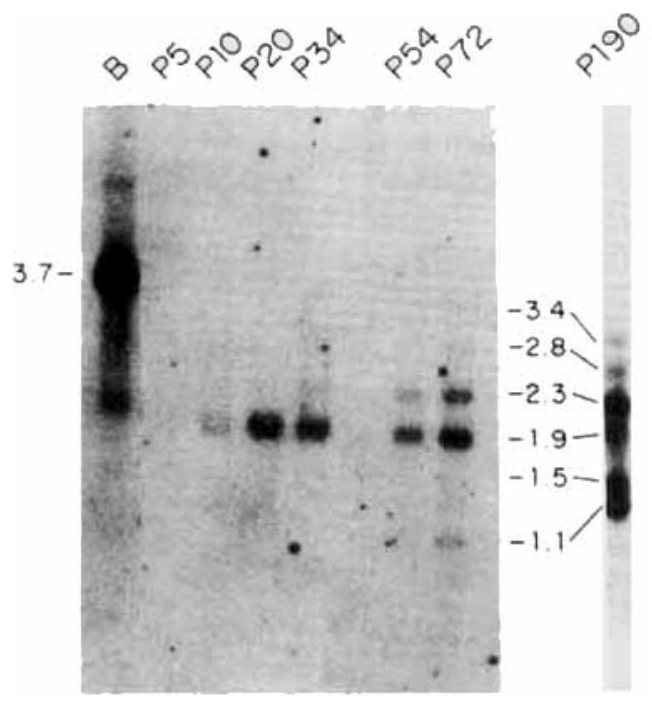

FIG. 6. $\mathrm{GAD}_{67}$ RNAs in postnatal testicular development. Each lane of the northern blot contains $3 \mu \mathrm{g}$ of poly $(\mathrm{A})^{+}$RNA from testes at different stages of postnatal development except the rat brain (B) lane, which contains $1 \mu \mathrm{g}$ of poly(A) ${ }^{+}$RNA. Postnatal days 5 , $10,20,34,54,72$, and $190, \mathrm{P} 5, \mathrm{P} 10, \mathrm{P} 20, \mathrm{P} 34, \mathrm{P} 54, \mathrm{P} 72$, and P190, respectively. 
regulation by PLP, by other metabolites that may effect GAD-PLP interactions, or by ovarian hormones themselves.

GABA may also participate in the endocrine function in testis. GABA stimulates the production of testosterone in whole decapsulated testis (Ritta et al., 1987) and in testicular interstitial cell membranes (Ritta et al., 1991). Binding assays show the presence of GABA $A_{A}$ and $G_{A B A}$ receptors in testicular intertitial cells and purified Leydig cells (Ritta et al., 1991). We find $m R N A s$ of the $\alpha_{1}$ subunit of the $\mathrm{GABA}_{\mathrm{A}}$ receptor expressed in the Leydig cell line LC-540 (N. J. K. Tillakaratne, unpublished data). GABA may also have a direct effect on spermatozoa because $\mathrm{GABA}_{\mathrm{A}}$-type binding sites are present on seminal membranes (Erdö and Wekerle, 1990). Persson et al. (1990) suggested GABA as an energy source for flagellar action. This is based on presence of GAD-like immunoreactivity in the midpiece of spermatozoa, which also contains a sheaf of mitochondria. In support of this idea, sodium valproate (an inhibitor of GAD and GABA transaminase) decreases sperm number and sperm motility in rats (Cohn et al., 1982).

\section{Are GADs in nonneural tissues the same as brain GADs?}

Oviduct and testis contain GADs that are similar to those in brain both with respect to common epitopes and common coding sequences as detected by highstringency hybridization. If the nonneural GADs are similar to the two brain GAD forms $\left(G_{A D} D_{67}\right.$ and $G_{A D}$ ), one would expect to see a similarity between GAD RNAs or proteins. We did not detect any GAD RNAs or proteins to both forms of GAD in liver, kidney, heart, adrenal gland, uterus, intestine, lung, or pancreas. GAD forms similar to that in brain may be present only in a few specialized cells in these peripheral tissues, thus being undetected when whole organs or tissues are assayed. This is certainly the case for $\beta$ cells in the pancreas, where this laboratory has shown immunoreactivity to both $\mathrm{GAD}_{65}$ and $\mathrm{GAD}_{67}$ forms (D. L. Kaufman et al., manuscript submitted; N. J. K. Tillakaratne, unpublished data). GAD activity in liver and kidney is higher than that of the oviduct and testis. The presence of GABA and GAD is well documented in isolated hepatocytes (Minuk, 1986) and in kidney tubules (Goodyer et al., 1980, 1982). GAD activity in these nonneural tissues might derive from other GAD forms, such as those reported by Wu et al. (1986a), Denner et al. (1987), and Huang et al. (1990).

The molecular biological, immunological, and enzymological data presented here show that $\mathrm{GAD}_{65}$ and $\mathrm{GAD}_{67}$, at least, are present in a restricted set of nonneural cells. Our results thus lend strong support for the suggestion that GABA plays a physiological role other than neurotransmission.

Acknowledgment: We are grateful to Carolyn Houser and Barbara Tibbs for helping us with immunohistochemistry.
We also thank Dona Chikaraishi for the rat brain cDNA library and David Gottlieb for providing us with the GAD6 monoclonal antibody. We are grateful to the following people for helpful discussions: Bu Dingfang, Sophie Feldblum, Gretchen Frantz, Daniel Kaufman, Helen Kim, George Lawless, Lali Medina-Kauwe, Cathy Pinal, Christian Ruppert, Jose Segovia, and Robert Weatherwax. This work was supported by grants NS 20356 and 22256 to A. J. Tobin from the NINCDS. N. J. K. Tillakaratne was partially supported by fellowships from the American Association of University Women and Phi Beta Kappa.

\section{REFERENCES}

Apud J. A., Tappaz M. L., Celotti F., Negri-Cesi P., Masotto C., and Racagni G. (1984) Biochemical and immunochemical studies on the GABAergic system in the rat fallopian tube and ovary. J. Neurochem. 43, 120-125.

Baekkeskov S., Aanstoot H., Christgaus S., Reetz A., Solimena M., Cascalho M., Folli F., Richter-Oleson H., and DeCamilli P. (1990) Identification of the 64K auto-antigen in insulin-dependent diabetes as the GABA-synthesizing enzyme glutamic acid decarboxylase. Nature 347, 151-156.

Boisvieux-Ulrich E., Laine M.-C., and Sandoz D. (1987) In vitro effects of benzodiazapines on ciliogenesis in the quail oviduct. Cell Motil. Cytoskeleton 8, 333-344.

Bradford M. M. (1976) A rapid and sensitive method for the quantitation of microgram quantities of protein utilizing the principle of protein-dye binding. Anal. Biochem. 72, 248-254.

Celloti F., Apud J. A., Rovescalli A. C., Melcangi R. C., Negri-Cesi P., and Racagni G. (1986) The GABAergic extrinsic innervation of the rat fallopian tubes: biochemical evidence and endocrine modulation, in Advances in Biochemical Psychopharmacology, Vol. 42: GABA and Endocrine Function (Racagni G., and Donoso A. O., eds), pp. 251-264. Raven Press, New York.

Celloti F., Apud J. A., Rovescalli A. C., Negri-Cesi P., and Racagni G. (1987) Possible involvement of ovarian mechanisms other than estrogen-progesterone secretion in the regulation of glutamic acid decarboxylase activity of the rat fallopian tubes. Endocrinology 120, 700-706.

Chang Y.-C. and Gottlieb D. 1. (1988) Characterization of the proteins purified with monoclonal antibodies to glutamic acid decarboxylase. J. Neurosci. 8, 2123-2130.

Chen C. C., Mather J. P., Morris P. L., and Bardin C. W. (1984) Expression of pro-opiomelanocortin-like gene in the testis and epididymis. Proc. Natl. Acad. Sci. USA 81, 5672-5675.

Chirgwin J. M., Przybyla A. E., MacDonald R. J., and Rutter W. J. (1979) Isolation of biologically active ribonucleic acid from sources enriched in ribonuclease. Biochemistry 18, 5294-5299.

Church G. M. and Gilbert W. (1984) Genomic sequencing. Proc. Natl. Acad. Sci. USA 81, 1991-1995.

Cohn D. F., Homonnai Z. T., and Paz G. F. (1982) The effect of anticonvulsant drugs on the development of male rats and their fertility. J. Neurol. Neurosurg. Psychiatry 45, 844-846.

Collard M. W., Day R., Akil H., Uhler M. D., and Douglass J. O. (1990) Sertoli cells are the primary site of prodynorphin gene expression in rat testis: regulation of mRNA synthesis and peptide secretion by cAMP analogs in cultured cells. Mol. Endocrinol. 4, 1488-1496.

Del Rio R. M. (1981) $\gamma$-Aminobutyric acid system in rat oviduct. J. Biol. Chem. 256, 9816-9819.

Denner L. A. and Wu J.-Y. (1985) Two forms of rat brain glutamic acid decarboxylase differ in their dependence on free pyridoxal phosphate. J. Neurochem. 44, 957-965.

Denner L. A., Wei S. C., Lin H. S., Lin C.-T., and Wu J-Y. (1987) Brain L-glutamate decarboxylase: purification and subunit structure. Proc. Natl. Acad. Sci. USA 84, 668-672.

Dorrington J. H. and Fritz I. B. (1975) Cellular localization of 5alpha-reductase and 3-alpha-hydroxysteroid dehydrogenase in the seminiferous tubule of the rat testis. Endocrinology 96, 879889. 
Duvilanski B. H., del Carmen Diaz M. C., Lasaga M., and Seilicovich A. (1985) L-Glutamate decarboxylase activity in the ovary and fallopian tube during the estrous cycle. IRCS Med. Sci. (Biochem.) 13, 81 .

Erdö S. L. (1984) Alteration of GABA levels in ovary and fallopian tube of the pregnant rat. Life Sci. 34, 1879-1884.

Erdö S. L. and Amenta F. (1986) Characterization and localization of high-affinity GABA uptake in rabbit oviduct. Eur. J. Pharmacol. 130, 287-294.

Erdö S. L. and Kiss B. (1986) Presence of GABA, glutamate decarboxylase, and GABA transaminase in peripheral tissues: a collection of quantitative data, in GABAergic Mechanisms in the Mammalian Periphery (Erdö S. L. and Bowery N. G., eds). pp. 5-17. Raven Press, New York.

Erdö S. L. and Wekerle L. (1990) $\mathrm{GABA}_{\mathrm{A}}$ type binding sites on membranes of spermatozoa. Life Sci. 47, 1147-1151.

Erdö S. L. and Wolff J. R. (1990) $\gamma$-Aminobutyric acid outside the mammalian brain. J. Neurochem. 54, 363-372.

Erdö S. L., Kiss B., and Szporny L. (1984) Comparative characterization of glutamate decarboxylase in crude homogenates of oviduct, ovary, and hypothalamus. $J$. Neurochem. 43, 15321537.

Erdö S. L., Somogyi J., Hamori J., and Amenta F. (1986) Light- and electron-microscopic visualization of gamma-aminobutyric acid and GABA-trans-aminase in the oviduct of rats. Predominant occurrence in epithelium. Cell Tissue Res. 244, 621-624.

Erdö S. L., Joó F., and Wolff J. R. (1989) Immunohistochemical localization of glutamate decarboxylase in the rat oviduct and ovary: further evidence for non-neural GABA systems. Cell Tissue Res. 255, $431-434$.

Erlander M. G. and Tobin A. J. (1991) The structural and functional heterogeneity of glutamate decarboxylase: a review. Neurochem. Res. 16, 215-226.

Erlander M. G., Tillakaratne N. J. K., Feldblum S., Patel N., and Tobin A. J. (1991) Two genes encode distinct glutamate decarboxylases with different responses to pyridoxal phosphate. Netron 7, 91-100.

Feinberg A. P. and Vogelstein B. (1984) Addendum: a technique for radiolabeling DNA restriction endonuclease fragments to high specific activity. Anal. Biochem. 137, 266-267.

Fernandez I., Martin del Rio R., and Orensanz L. M. (1985) Surgical ablation of oviductal extrinsic innervation changes GABA levels in the rat Fallopian tube. Life Sci. 36, 1733-1737.

Fernandez-Pardal J., Gimeno M. F., and Gimeno A. L. (1984) The presence of GABA in ovarian, tubal and uterine rat tissue and the influence of estrogens. IRCS Med. Sci (Biochem.) 12, 706.

Goodyer P. R., Lancaster G., Villeneure M., and Scriver C. R. (1980) The relationship of 4-aminobutyric acid metabolism to ammoniagenesis in renal cortex. Biochim. Biophys. Acta 633, 191200.

Goodyer P. R., Mills M., and Scriver C. R. (1982) Properties of gamma-aminobutyric acid synthesis by rat renal cortex. Biochim. Biophys. Acta 716, 348-357.

Huang W.-M., Reed-Fourguet L., Wu E., and Wu J.-Y. (1990) Molecular cloning and amino acid sequence of brain L-glutamate decarboxylase. Proc. Natl. Acad. Sci. USA 87, 8491-8495.

Jessen K. R., Mirsky R., Dennison M. E., and Burnstock G. (1979) GABA may be a neurotransmitter in the vertebrate peripheral nervous system. Nature 281, 71-74.

Karkun J. V. (1979) Recent advances on the endocrinology of the mammalian oviduct, in Recent Advances in Reproduction and Regulation of Fertility' (Talwar G. P., ed), pp. 189-199. Elsevier/ North Holland Biomedical Press, Amsterdam.

Kataoka Y., Gutman Y., Guidotti A., Panula P.. Wroblewski J., Cosenza-Murphy D.. Wu J. Y., and Costa E. (1984) Instrinsic GABAergic system of adrenal chromaffin cells. Proc. Natl. Acad. Sci. USA 81, 3218-3222.

Kaufman D. L., McGinnis J. F., Krieger N. R., and Tobin A. J. (1986) Brain glutamate decarboxylase cloned in $\lambda$-gt-11: fusion protein produces $\gamma$-aminobutyric acid. Science 232, 1138-1140.

Kaufman D. L., Houser C. R., and Tobin A. J. (1991) Two forms of the GABA synthetic enzyme glutamate decarboxylase have distinct intraneuronal distributions and cofactor interactions. J. Neurochem. 56, 720-723.

Khrestchatisky M., MacLennan A. J., Tillakaratne N. J. K., Chiang M.-Y, and Tobin A. J. (1991) Sequence and regional distribution of the mRNA encoding the $\alpha 2$ polypeptide of rat $\gamma$-aminobutyric

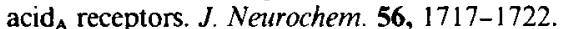

Kilpatrick D. L. and Borland K. (1987) Differential expression of two distinct forms of proenkephalin mRNA during development of the mouse testis. Ann. N. Y. Acad. Sci. 15, 315-317.

Kilpatrick D. L., Howells R. D., Noe M., Bailey C. L., and Udenfriend S. (1985) Expression of preproenkephalin-like mRNA and its peptide products in mammalian testis and ovary. Proc. Natl. Acad. Sci. USA 82, 7467-7469.

Kobayashi Y., Kaufman D. L., and Tobin A. J. (1987) Glutamic acid decarbox ylase cDNA: nucleotide sequence encoding an enzymatically active protein. J. Neurosci. 7, 2768-2772.

Krieger N. R. and Heller J. S. (1984) Localization of GAD within laminae of rat olfactory tubercle. J. Neurochem. 33, 299-309.

Legay F., Henry S., and Tappaz M. (1987) Evidence for two distinct forms of native glutamic acjd decarboxylase in rat brain soluble extract: an immunoblotting study. J. Neurochem. 48, 1022-1026.

Louzan P., Gallardo M. G. P., and Tramezzani J. H. (1986) Changes of GABA content in the fermale rat genital tract, in $G A B A$ and Endocrine Function (Racagni G. and Donoso A. O., eds), pp. 283-290. Raven Press, New York.

Maniatis T., Fritsch E. F., and Sambrook J. (1982) Molecular Cloning. A Laboratory Manual, p. 202. Cold Spring Harbor Laboratory, Cold Spring Harbor, New York.

Martin D. L. (1987) Regulatory properties of brain glutamate decarboxylase. Cell. Mol. Neurobiol. 7, 237-253.

Meistrish M. L., Bruce W. R., and Clermont Y. (1973) Cellular composition of mouse testis cells following velocity sedimentation separation. Exp. Cell Res. 79, 213-227.

Minuk G. Y. (1986) GABAergic mechanisms and their functional importance in the liver, in GABAergic Mechanisms in the Mammalian Periphery (Erdö S. L. and Bowery N. G., eds), pp. 325337. Raven Press, New York.

Morales C., Hugly S., and Griswold M. D. (1987) Stage-dependent levels of specific mRNA transcripts in Sertoli cells. Biol. Reprod. 36, $1035-1046$.

Murashima Y. L. and Kato T. (1986) Distribution of $\gamma$-aminobutyric acid and glutamate decarboxylase in the layers of rat oviduct. J. Neurochem. 46, 166-172.

Oertel W. H., Schmechel D. E., Weise V. K., Ransom D. H., Tappaz M. L., Krutzch H. C., and Kopin I. J. (1981a) Comparison of cysteine sulphinic acid decarboxylase isozymes and glutamic acid decarboxylase in rat liver and brain. Neuroscience 6, 2701-2714.

Oertel W. H., Schmechel D. E., Tappaz M. L., and Kopin I. J. (1981b) Production of a specific antiserum to rat brain glutamic acid decarboxylase by injection of an antigen-antibody complex. Neuroscience 6, 2689-2700.

Persson H., Delto-Huikko M., Metsis M., Söder O., Stefan B., Skog S., Hökfelt T., and Ritzén E. M. (1990) Expression of the neurotransmitter-synthesizing enzyme glutamic acid decarboxylase in male germ cells. Mol. Cell. Biol. 10, 4701-4711.

Pintar J. E., Schachter B. S., Herman A. B., Durgerian S., and Krieger D. T. (1984) Characterization and localization of proopiomelanocortin messenger RNA in the adult testis. Science 225, 632634.

Redburn D. A. and Schousboe A., eds (1987) Neurotrophic Activity of GABA During Development. Alan R. Liss, New York.

Ritta M. N.. Campos M. B., and Calandra R. S. (1987) Effect of GABA and benzodiazepines on testicular androgen production. Life Sci. 40, 791-798.

Ritta M. N., Campos M. S., and Calandra R. S. (1991) Coexistence of $\gamma$-aminobutyric Acid type A and type $B$ receptors in testicular interstitial cells. J. Neurochem. 56, 1236-1240.

Rorsman P., Berggre P.-O., Bokvist K., Ericson H., Mohler H., Ostenson C.-G., and Smith P. A. (1989) Glucose-inhibition of glucagon secretion involves activation of $\mathrm{GABA}_{\mathrm{A}}$ receptor chloride channels. Nature 341, 233-236.

Russell L. D., Alger L. E., and Neguin L. G. (1987) Hormonal control 
of pubertal spermatogenesis. Endocrinology 120, 1615-1632.

Segovia J., Tillakaratne N. J. K., Whelan K., Tobin A. J., and Gale K. (1990) Parallel increases in striatal glutamic acid decarboxylase activity and $m R N A$ levels in rats with lesions of the nigrostriatal pathway. Brain Res. 529, 345-348.

Spink D. C., Porter T. G., Wu S. J., and Martin D. L. (1985) Characterization of three kinetically distinct forms of glutamate decarboxylase from pig brain. Biochem. J. 231, 695-703.

Tillakaratne N. J. K. and Tobin A. J. (1986) Glutamic acid decarboxylase (GAD) messenger RNA in brain and peripheral tissues of rat. (Abstr) Soc. Neurosci. Abstr. 12, 1458.

Tobin A. J. (1989) Structure and regulation of the gene for the glutamate decarboxylase: a candidate gene for neuropsychiatric and neurological disease, in Molecular Neurobiology, Proceedings of the First NIMH Conference (Zalcman S. and Scheller R., eds), pp. 165-182. U.S. Department of Health and Human Services, Rockville, Maryland.

Vincent S. R., Hökfelt T., Wu J.-Y., Elde R. P., Morgan L. M., and Kimmel J. R. (1983) Immunohistochemical studies of the GABA system in the pancreas. Neuroendocrinology 36, 197-204.

Whelan D. T., Scriver C. R., and Mohyuddin F. (1969) Glutamic acid decarboxylases and gamma-aminobutyric acid in mammalian kidney. Nature 224, 916-917.

Wood T. L., Frantz G. D. Menkes J. H.. and Tobin A. J. (1986)
Regional distribution of messenger RNAs in postmortem human brain. J. Neurosci. Res. 16, 311-324.

Wu J.-Y. (1977) A comparative study of L-glutamate decarboxylase from mouse brain and bovine heart with purified preparations. J. Neurochem. 28, 1359-1367.

Wu J.-Y. and Roberts E. (1973) Comparative studies of L-glutamate decarboxylases from mouse brain and kidney. (Abstr) Am. SOC Neurochem. 4, 70.

Wu J.-Y., Chude O., Wein J., and Roberts E. (1978) Glutamate decarboxylase from neural and non-neural tissues. J. Neurochem. 30, 849-857.

Wu J.-Y., Denner L. A., Wei S. C., Lin C.-T., Song G.-X., Xu Y. F., Liu J. W., and Lin H. S. (1986a) Production and characterization of polyclonal and monoclonal antibodies to rat brain L-glutamate decarboxylase. Brain Res. 373, 1-14.

Wu J.-Y., Lin C.-T., Lin H., Xu Y., Liu J. W., Hwang B. H.. and Wei S. C. (1986b) Immunochemical characterization and im munohistochemical localization of glutamate decarboxylase and GABA transaminase in peripheral tissues, in GABAergic Mech. anisms in the Mammalian Periphery (Erdö S. L. and Bowery N. G., eds), pp. 19-34. Raven Press, New York.

Wuenschell C. W., Fisher R. S., Kaufman D. L., and Tobin A. J. (1986) In situ hybridization to localize mRNA encoding the neurotransmitter synthetic enzyme glutamate decarboxylase in mouse cerebellum. Proc. Natl. Acad. Sci. USA 83, 6193-6197. 